\title{
Evaluation Criteria and Analysis of Overall Success of Students in Secondary Schools of Anamorava
}

\author{
Nazyktere Hasani ${ }^{1}$ \\ Lavdim Terzıu² \\ ${ }^{1}$ High school, Gymnasium, "Zenel Hajdini", Gjilan \\ Email: nhasani14@hotmail.com \\ 2Primary School "Halil Alidema" - Pozheran - Viti \\ Email: lavdimterziu@gmail.com
}

\section{Doi:10.5901/jesr.2014.v4n2p67}

\begin{abstract}
Overall success of the students at the end of the school year is an important aspect of reflection of student achievement based on their skills and learning skills, and successful or failed work of the overall student throughout the school year. In this paper student assessment system is included and the analysis of their overall success in schools of Anamorava Region for four academic years 2009/10, 2010/11, 2011/12 and 2012/13. The purpose of this study was to determine the extent and differences overall success of students in vocational schools and gymnasiums in three municipalities. The methods of this study include a critical review and analyses of student achieve success. Findings from the data analysis show that there are differences between high school student success and Professional, also between municipalities. We distinguish the municipality of Gillan, where excellent success showed a higher percentage of students of Gymnasium in comparison with two other municipalities. This study is based on statistical data derived from the Municipal Director of Education of the three municipalities.
\end{abstract}

KeyWords: Evaluation system, success of students, high schools

\section{Introduction}

Education, as the one of the fundamental areas of development of a country, even in Kosovo is being given more importance in order to progress and its development by adapting to modern demands for a modern and advanced education with an increase of the quality of education. An important aspect of the field of education is the evaluation of students which shows students' achievement throughout the school year that is presented with assessment."Success in learning can be presented in synthetically form (cumulative), analytical (differentiated, individualized) and in their combination. Success in the synthetic form is presented with a cumulative grade-numbered from 1 to 5 , with words (insufficient, sufficient, good, very good, and excellent).... Through the analytical evaluation in concrete and more accurate, the qualitative level of knowledge adaption is presented. "(Shatri, 2006.449).Evaluation of students' achievement in different countries is caused by different assessment ways. In pre-university education in Kosovo the assessment is made by marks from one to five and in descriptive way for the selected subjects. Insufficient success of students represents the grade 1, sufficient success of the student presents grade 2, grade 3 represents the good success achieved by students, grade 4 represents the very good success achieved by students and grade 5 represents the excellent success achieved. Kraja (2009) related to the evaluation criteria states "For each mark there is a certain criteria. It is useful for the evaluation criteria to be defined by educational representatives, for each subject. These requirements affect the integration of teachers' opinions to evaluate students. This affects in the avoidance of subjectivity in the evaluation of students and increases the sense of responsibility. "(Kraja, 2009:328). The general success of the students at the end of the school year is an important aspect which reflects the overall state of students achievement in their work based on commitment, analytical skills and their skills throughout the school year, for a better success accomplishment.Rukiqi, 2012 in his book " Balanced teaching " in his study made by an analysis of student success in the physical education subject, of a class in Kosovo and a class in Sweden emphasizes that "The analysis that I made in a class of Kosovo with 19 students show that about $79 \%$ of students had a grade 5 which shows a total diversion from the normal distribution, directly we can conclude that there is a major error in the evaluation criteria. The same analysis I did in Sweden with a classroom with 18 students and the percentage of students with the highest grade is approximately 
around 11\% "(Rukiqi, 2012:100). The study is based on statistical data of the overall success of students from municipal Directory of Education of the three municipalities for the school years 2009/10, 2010/11, 2011/12 and 2012/13, analyzing the success of all students in secondary education, as in the general direction also in the professional one.

The purpose of this study was to determine the extent and differences of the overall success of students in vocational schools and gymnasiums in three municipalities. Objective of this study was: analysis, comparison and verification of the existence of differences between students' success in vocational schools and high schools as well as between municipalities; Let's reflect students' success of Anamorava region.

\section{Analysis and Interpretation of Statistical Data of the Overall Success of Middle School Students For the School Years 2009/10, 2010/11, 2011/12 And 2012/13}

Analysis of the overall success of middle school students at the municipal level in three municipalities: Gjilan, Kamenica and Viti is made on the basis of statistical data obtained from these municipal directors. Below the data of students overall success for the school years 2009/10, 2010/11, 2011/12 and 2012/13 are presented.

Table 1: The success of high school students at the end of the school year 2009/10

\begin{tabular}{|c|c|c|c|c|c|c|c|c|c|c|c|}
\hline \multirow[b]{2}{*}{$\begin{array}{l}\text { The school } \\
\text { year 2009/10 }\end{array}$} & \multirow{2}{*}{ 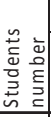 } & \multicolumn{2}{|c|}{ Excellent } & \multicolumn{2}{|c|}{ Very good } & \multicolumn{2}{|c|}{ Good } & \multicolumn{2}{|c|}{ Sufficient } & \multicolumn{2}{|c|}{ Have reiterated } \\
\hline & & Stu & $\%$ & Stu & $\%$ & Stu & $\%$ & Stu & $\%$ & Stu & $\%$ \\
\hline Gjilan & 7453 & 2531 & 33.96 & 1544 & 20.72 & 1612 & 21.63 & 1433 & 19.23 & 333 & 4.47 \\
\hline Kamenica & 2112 & 477 & 22.58 & 498 & 23.58 & 645 & 30.54 & 469 & 22.21 & 23 & 1.09 \\
\hline Viti & 2860 & 547 & 19.12 & 540 & 18.88 & 698 & 24.41 & 796 & 27.83 & 279 & 9.76 \\
\hline Total & 12425 & 3555 & 25.22 & 2582 & 21.06 & 2955 & 25.52 & 2698 & 23.09 & 635 & 5.1 \\
\hline
\end{tabular}

Source: Municipal Directorate of Education Gjilan, Kamenica and Year-Students' success of the municipal level schools

From the table 1 we see that, of the total number of 12425 students in three municipalities of Gjilan, Kamenica and Viti, during the school year 2009/10, with excellent success have passed 3555 students or 25.22 per cent, with very good success have passed 2582 students or 21.6 per cent, with good success have passed 2955 students or 25.52 percent, with sufficient success have passed 2698 students or 23.9 per cent and 635 students or 5.1 percent of them have repeated the grade, where among those students who have repeated the same grade, students without being evaluated are included. From these data we see that the percentage of students with excellent success is the same as that of students who have successfully passed well and precedes, then the percentage of students with insufficient success, while the lowest percentage is that with very good success by not considering the percentage of students who repeated the grade. Seeing the data for each municipality separately we note that a higher percentage of students with excellent success belongs to the municipality of Gjilan, Kamenica and then finally Viti. Also it is worth mentioning that for rational reasons we could not present all the data separately for vocational schools and gymnasiums, but we can say that high school students have shown better success compared to professional schools and that students of Gjilan gymnasium compared with the two municipalities have shown better success during this school year.

Table 2: The success of middle school students at the end of the school year 2010/11

\begin{tabular}{|c|c|c|c|c|c|c|c|c|c|c|c|}
\hline \multirow[b]{2}{*}{$\begin{array}{l}\text { School year } \\
2010 / 11\end{array}$} & \multirow{2}{*}{ 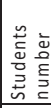 } & \multicolumn{2}{|c|}{ Excellent } & \multicolumn{2}{|c|}{ Very good } & \multicolumn{2}{|c|}{ Good } & \multicolumn{2}{|c|}{ Sufficient } & \multicolumn{2}{|c|}{ Have reiterated } \\
\hline & & Stu & $\%$ & Stu & $\%$ & Stu & $\%$ & Stu & $\%$ & Stu & $\%$ \\
\hline Gjilan & 7681 & 2812 & 36.61 & 1521 & 19.8 & 1797 & 23.4 & 1084 & 14.11 & 467 & 6.08 \\
\hline Kamenica & 2065 & 539 & 26.1 & 447 & 21.65 & 624 & 30.22 & 437 & 21.16 & 18 & 0.87 \\
\hline Viti & 3063 & 689 & 22.49 & 556 & 18.15 & 771 & 25.17 & 812 & 26.51 & 235 & 7.67 \\
\hline Total & 12809 & 4040 & 28.4 & 2524 & 19.87 & 3192 & 26.26 & 2333 & 20.59 & 720 & 4.87 \\
\hline
\end{tabular}

Source: Municipal Directorate of Education Gjilan, Kamenica and Year-School students' success of the municipal level schools. 
As we can see from table 2 of the total of 12809 students of the three municipalities, for the academic year 2010/11 excellent success have shown 4040 students or 28.4 percent of them, then good success have shown 3192 students or 26.26 percent of them, sufficient success have shown 2333 students or 20.59 per cent of them and in the end ranks the very good success, students 2524 or 19.87 per cent of them. Number of students respectively their percentage who have repeated their grade was 720 or 4.87 percent. Through this school year students of the municipality of Gjilan, compared with the two other municipalities, have shown a better excellent success, while students of the municipality of Kamenica have shown very good and good success, better than the students of the municipality of Gnjilane and Viti.

Table3: The success of middle school students at the end of the school year 2011/12

\begin{tabular}{|c|c|c|c|c|c|c|c|c|c|c|c|}
\hline \multirow[b]{2}{*}{$\begin{array}{l}\text { School year } \\
2011 / 12\end{array}$} & \multirow{2}{*}{ 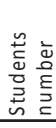 } & \multicolumn{2}{|c|}{ Excellent } & \multicolumn{2}{|c|}{ Very good } & \multicolumn{2}{|c|}{ Good } & \multicolumn{2}{|c|}{ Sufficient } & \multicolumn{2}{|c|}{ Have reiterated } \\
\hline & & Stu & $\%$ & Stu & $\%$ & Stu & $\%$ & Stu & $\%$ & Stu & $\%$ \\
\hline Gjilan & 7759 & 2775 & 35.76 & 1472 & 18.97 & 1768 & 22.79 & 1483 & 19.11 & 261 & 3.36 \\
\hline Kamen & 2006 & 469 & 23.38 & 433 & 21.58 & 753 & 37.54 & 329 & 16.4 & 22 & 1.1 \\
\hline Viti & 3048 & 742 & 24.34 & 476 & 15.62 & 728 & 23.88 & 912 & 29.92 & 190 & 6.23 \\
\hline otal & 12813 & 3986 & 27.83 & 2381 & 18.72 & 3249 & 28.07 & 2724 & 21.81 & 473 & 3.56 \\
\hline
\end{tabular}

Source: Municipal Directorate of Education Gjilan, Kamenica and Year-Students' success of the municipal level schools

In the table 3 presented above the data of the success of the students during the school year 2011/12 is presented. Excellent successes have shown 3986 students or 27.83 per cent of the total number of students enrolled 12813 . Very good success have shown a total of 2381 students or 18.72 percent of them, good success have shown 3249 students or 28.07 percent, sufficient success have shown 2724 students or 21.81 per cent, while 473 students or 3.56 percent of them have repeated the grade. These data indicate that the excellent success ranks first, then the good success, sufficient and in end the very good success, without introducing the low success. If you look at the data of the excellent success, we conclude that the municipality of Gjilan precedes the highest percentage, then Viti and Kamenica.The highest percentage of the very well and good success has the municipality of Kamenica and a higher percentage of the sufficient success has Municipality of Viti. The highest percentage of those who have repeated the grade among the three municipalities had the Municipality of Viti.

Table 4: The success of middle school students at the end of the school year 2012/13

\begin{tabular}{|c|c|c|c|c|c|c|c|c|c|c|c|}
\hline \multirow[b]{2}{*}{$\begin{array}{l}\text { School year } \\
2012 / 13\end{array}$} & \multirow{2}{*}{ 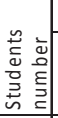 } & \multicolumn{2}{|c|}{ Excellent } & \multicolumn{2}{|c|}{ Very good } & \multicolumn{2}{|c|}{ Good } & \multicolumn{2}{|c|}{ Sufficient } & \multicolumn{2}{|c|}{ Have reiterated } \\
\hline & & Stu & $\%$ & Stu & $\%$ & Stu & $\%$ & Stu & $\%$ & Stu & $\%$ \\
\hline Gjilan & 7551 & 2673 & 35.4 & 1482 & 19.63 & 1795 & 23.77 & 1305 & 17.28 & 296 & 3.9 \\
\hline Kamenica & 1868 & 426 & 22.81 & 449 & 24.04 & 627 & 33.57 & 359 & 19.22 & 1 & 0. \\
\hline Viti & 2640 & 639 & 24.2 & 453 & 17.16 & 744 & 28.18 & 617 & 23.37 & 187 & $7 . C$ \\
\hline tal & 12059 & 3738 & 27.47 & 2384 & 20.28 & 3166 & 28.51 & 2281 & 19.96 & 490 & 3. \\
\hline
\end{tabular}

Source: Municipal Directorate of Education Gjilan, Kamenica and Year-Students' success of the municipal level schools

Table 4 gives us these data: Of the total of 12059 students, with the excellent success have passed 3738 students or 27.47 per cent of them, with the very good success 2384 students have passed or 20.28 percent, with the good success have passed 3166 students or 28.51 percent, with the sufficient success have passed 2281 students or 19.96 percent of them. The number of students in this school year that have repeated the grade is 490 or 3.78 percent. Higher percentage of the excellent success of students has the Municipality of Gjilan, then Viti and Kamenica. A higher percentage of the very good successes have shown the students of Kamenica and then those of Viti. With the sufficient success precedes the municipality of Viti. Regarding percentage of students who have repeated the grade, the Municipality of Kamenica 
has the lowest percentage in comparison with two other municipalities.

\subsection{Comparative data of the success of students from three municipalities}

Table 5: Comparative data of student success in \% for four school years

\begin{tabular}{|l|l|l|l|l|l|}
\hline School year & Excellent & Very good & Good & Sufficient & Have reiterated \\
\hline $2009 / 10$ & $25.22 \%$ & $21.06 \%$ & $25.52 \%$ & $23 \%$ & $5.10 \%$ \\
\hline $2010 / 11$ & $28.40 \%$ & $19.87 \%$ & $26.26 \%$ & $20.59 \%$ & $4.87 \%$ \\
\hline $2011 / 12$ & $27.83 \%$ & $18.72 \%$ & $28.07 \%$ & $21.81 \%$ & $3.56 \%$ \\
\hline $2012 / 13$ & $27.47 \%$ & $20.28 \%$ & $28.51 \%$ & $19.96 \%$ & $3.78 \%$ \\
\hline
\end{tabular}

In Table 5 comparative data of the students' success in three municipalities during the school years 2009/10, 2010/11, 2011/12 and 2012/13 are presented. From these data in percentage we have an increase of the excellent success, where in 2009/2010 year we have 25.22 percent excellent success, a percentage which increases to 28.40 percent in the school year 2010/11, then in 2011/12 year have a slight decrease with 27.83 per cent and in 2012/13 year to 27.47 percent. If we compare the above data for the very good success, we will see that from the academic year 2009/10 to 2011/12 we have a percentage decrease by 21.6 percent to 18.72 percent, while in the school year 2012/13 we have a percentage increase in 20.28 percent. The percentage of students with a good success in the academic year 2009/10 was 25.52 percent, in the school year 2010/11 the percentage rises to 26.26 percent, in the school year 2011/12 to 28.7 percent and in the academic year 2012/13 we have also a slight increase with 28.51 percent. If we compare the data for the sufficient success and for the ones who have repeated the grade, we note that from the academic year 2009/10 until the academic year 2012/13 there was a decrease in the percentage of this success.

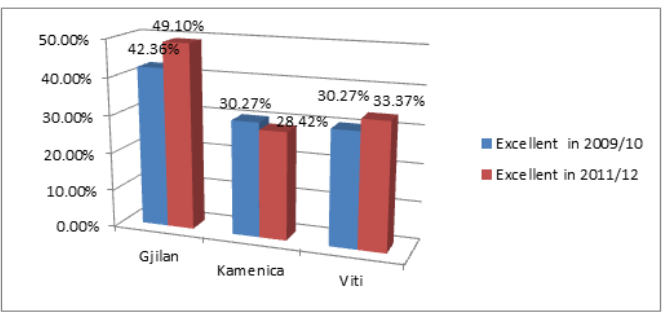

Graph 1: Comparative data of the excellent success in $\%$ of high school students from three municipalities

Based on the data in Figure 1 we see that during the school year 2009/10 in municipality of Gjilan, the percentage of students with excellent success was 42.36 per cent; in the municipality of Kamenica 30.27 percent and in municipality of Viti was 30.27 percent. In the academic year 2012/13 we have an increase of the percentage of students with excellent success in the municipality of Gjilan in 49.10 percent; in the municipality of Kamenica we have a percentage reduction in 28.42 percent and in municipality of Viti the excellent success had an increase in 33.37 percent. From the data in the table above we see that the largest percentage of the excellent success is in the municipality of Gjilan.

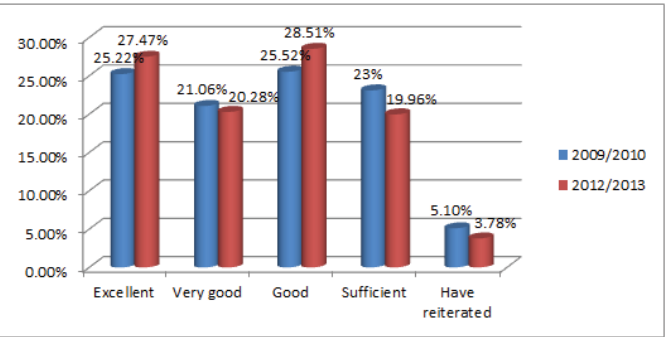

Graph 2: Comparative data in \% of students' success for the school years 2009/2010 and 2012/13 
Based on the data of the graph 2 and comparing these data for school years 2009/10 and 2012/13, shows that during the school year 2009/10 excellent success have shown 25.22 percent of students compared with 27.47 per cent of students that have shown in 2012/13, and we have a growth rate of 2.25 percent. In 2009/10 the percentage of the very good success was and 21.06 per cent, whereas in the academic year 2012/13 was 20.28 per cent where we have a difference of a decline percentage, decline for 0.78 per cent. In the academic year 2009/10 the percentage of the good success was 25.52 percent with a total of 12,425 students compared with the number of students 12,059 in 2012/13 with a difference of reducing the number of students 366 students, with an increase of 2.99 percentage percent. In 2012/13 year there was a decrease in the percentage of the sufficient success 19.96 percent compared with the school year 2009/10 where we had 23 percent, with a difference of reducing the percentage of 3.04 percent. The percentage of students who did not pass the grade in the school year 2009/10 was 5.10 per cent while in the school year 2012/13 it was 3.78 percent, with a difference of percentage reduction 1.31 percent. With this it is proved that students' excellent success of professional school is lower than of students in high schools, but we do not have any big difference of this success.

\section{Obtained Conclusions from the Analysis of Student Success}

- Excellent success and good success have shown approximately an equal percentage of school students for the four academic years, and a percentage nearly approximate of students have shown very good and sufficient success.

- In the school year 2009/10, from the total number of 12425 students, an excellent success have shown 3555 students or 25.22 per cent of them, a very good success have shown 21.06 percent, a good success 25.52 percent, a sufficient success 23.9 percent, that is implied that we do not have a significant difference in percentage of students at all levels of evaluation.

- In the academic year 2012/13 we have a percentage increase for 2.25 percent of the excellent success, for the very good success we have a difference of percentage decrease of 0.78 percent, for the good success we have a difference of the students' number decrease, 366 students, with a percentage increase 2.99 percent, for the percentage of the sufficient success we have a decrease difference of the percentage of 3.04 percent and for them who did not pass the grade, we have a decrease difference of the percentage of 1.31 percent.

- The school year 2010/11 was a school year that is characterized by a high percentage of the excellent success of 28.4 percent in comparison with other school years.

- The year 2012/13 caught us with a decrease in the percentage of students who have not passed the grade of 3.78 percent, compared to the school year 2009/10 where we have 5.10 per cent of them, which indicates a greater commitment of students in learning.

- From the data of success of the students of vocational schools and gymnasiums we have noticed that there is a difference of the success of these two directions, where high school students in four school years have shown a better success than students of vocational schools, which makes us pose the questions which should be studied: Why the success of students in vocational schools is lower than in gymnasiums? What are the main factors of the lower success in vocational schools?

\section{References}

Drejtoria Komunale e Arsimit,Gjilan ,Kamenicë dhe Viti. Suksesi i shkollave të mesme në Nivel Komunal 2009,2010,2011,2012, 2013.

[Municipal Directorate of Education Gjilan, Kamenica and Viti. The success of secondary schools in the municipal level]

Grgin, T. (1986), Školska dokimologija. Zagreb: Školska knjiga.

Kraja,M (2009) Pedagogjia. [ Pedagogy]. Tiranë,328 :Shtëpia botuese"Mirgeeralb"

Murati,Xh(2007).Organizimi i mësimit. [ The teaching organization]. Tetovë:Shtëpia botuese "Çabej"

Rukiqi,Sh(2012) Mësimdhënie e balancuar. [ Balanced teaching]. Prishtinë,100 Shatri,B.(2006).Arsimi fillor në Kosovë në shekullin XX. Primary education in Kosovo during the XX century].Prishtinë, 449 : Shtëpia botuese"Libri Shkollor"

http://www.srednja.hr/Zbornica/Nastava/Ravnatelji-srednjih-skola-Ima-vaznijih-stvari-od-ukidanja-opceg-uspjeha $\quad$ [seen $\quad 1 / 9 \quad 2014$ 10:17pm]

http://bib.irb.hr/datoteka/504029.1_Bratanic_Marsic_2004_relacije_izmedju_gledista_Napredak.pdf [seen 1/9/2014]

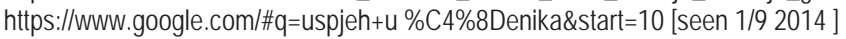

